\title{
4. PNG: Threats to media freedom and FOI
}

\section{COMMIDNIARY}

In PNG, the threats to media freedom and freedom of information include political and economic threats against the media and patronage of journalists. Journalists become silenced or 'tamed' when they accept payment from powerful individuals, corporations, political parties and corrupt institutions to see nothing, hear nothing and say or write nothing about the illegal and corrupt excesses of powerful political and economic players.

\section{SUSUVE LAUMAEA}

Interim co-chair, Pacific Freedom Forum, Port Moresby

\begin{abstract}
7 REEDOM OF INFORMATION and the right to know are universal rights of every man, woman and child on Planet Earth. That freedom and right are aptly pronounced in Article 19 of the Universal Declaration of Human Rights and I quote:
\end{abstract}

Everyone has the right to freedom of opinion and expression; this right includes freedom to hold opinions without interference and to seek, receive, and impart information and ideas through any media and regardless of frontiers.

The UNESCO World Press Freedom Day theme is noble but for freedom of information and the right to know to be embraced universally-especially in evolving and emerging nations such as those of the Pacific region-the campaign must come with funding and technical resources give strength and capacity to outreach programmes, advocacies, skills training and capacity building initiatives. Merely paying lip-service to these ideals, while expecting media practitioners, media freedom advocates, academics and trainers of freedom of information, right to know, freedom of expression and freedom of the press to work with nothing to achieve something is an exercise in futility. UNESCO outreach programmes with respect to the theme of this year's World Press Freedom Day and Article 19 must be well funded, proactive and 
objective-driven. Those nations that receive UNESCO assistance to implement the WPFD theme must then report on the progress of their endeavours at next year's WPFD global summit.

The topic we have been given to discuss and share is really an opportunity to revisit the sacred values of freedom of information and freedom to express, analyse, interpret and disseminate information that can inform, educate and shape society for the betterment of all humankind. I view freedom of information, the right to know vital information and data on public and national affairs and the freedom to express such information simply and effectively for understanding and use by the community at large as central to the role of journalists and news media they work for.

So, what are the threats to media freedom and freedom of information in the Pacific? Responses to this question may vary from nation to nation subject to the prevailing economic, social and political and cultural situations in respective Pacific states. In order to identify and understand what may be perceived as threats to media freedom and freedom of information in the context of the Pacific region outside of Australia and New Zealand it is equally important to identify and understand the underlying strengths, weaknesses, opportunities and threats confronting media and media practitioners in the small island states of Melanesia, Polynesia and Micronesia.

In the context of Papua New Guinea especially, and the Pacific Freedom Forum (PFF) in general, let me say there are strengths we can draw on, weaknesses we can convert to positives, opportunities we can harness and share and threats we can neutralise.

Media content - whether written for newspaper, radio or television-is a mirror-reflection of events and developments in our nation states. Those wielding powerful political and economic influence often do not like written, spoken or viewed journalism about their actions and their public utterances and regularly deny that they actually did or said what was published by a newspaper, announced on the radio or viewed on the television. When powerful economic and political forces turn against the media over what is written, said or viewed, they forget that they create the news and the media merely reports on the economic and political players.

\section{Specific threats}

In my view, the major threats to freedom of the media and freedom of information are: 
1. Political and economic threats against and patronage of journalists: Journalists become silenced or 'tamed' when they are paid by powerful individuals, corporations, political parties and corrupt institutions to see nothing, hear nothing and say or write nothing about the illegal and corrupt excesses of powerful political and economic players. Wealthy advertisers may threaten to withdraw their advertising accounts thereby effectively forcing editors to 'spike' public interest stories that are seen to damage the corporate image of the advertiser. Further threats in this category include lawsuits, threats to deport journalists if they are foreigners and threats to expropriate media ownership if they are foreign-owned.

2. Management Prerogative: Management Prerogative is a situation where the management of newspapers, radio and television decide what the news content should be. It is a form of in-house censorship where editors, publishers and the top management team of respective media organisations choose what story is published or broadcast, and what is not. They declare a 'no-go-zone' for certain news stories affecting powerful individuals, advertisers and corporations. It may be done subtly but over time it builds up to become a permanent culture of bias and manipulation of the truth, so that news is written in the 'management way' in order to appease advertisers and sources of revenue streams of newspapers, radio and television stations. Only when government officials and other political influences desist from applying censorship pressures on news outlets will the chances of wealthy individuals and business corporations taking out lawsuits against media organisations be minimised or neutralised.

3. Military dictatorships: Freedom of information, freedom of expression and freedom of the press become manipulated to serve the interest of the military dictatorship. Rules are changed, and freedom of information and the ability to express, publish or broadcast viewpoints freely are curtailed or totally removed. One Pacific Island nation, Fiji, is under a military dictatorship at present and press freedom, freedom of information and freedom of expression have become very rare luxuries for the people of that island nation.

Generally, much of the perceived threats against press freedom, freedom of information and the right to know as well as freedom of expression come as the 
result of the pursuit of the truth by journalists. Dictatorships tend to suppress the media when it tries to monitor, scrutinise, interpret and assess political and economic power, analyse whether or not power becomes self-serving for the wielder and to investigate whenever power is used corruptly to the detriment of the people's livelihood and their right to happiness, good health and prosperity.

The strength of Papua New Guinea media comes from Section 46 of our National Constitution which provides for freedom of expression as a qualified right of every citizen. That right has been there since the PNG National Constitution came into force on 16 September 1975-the date when Papua New Guinea became an independent nation-state.

Armed with this constitutionally-guaranteed freedom, the impression one would get would be that the PNG media is relatively free and open, up-beat and lively, robust and vibrant to the extent that we have lively sparring sessions with the governing executive, legislature and judiciary.

\section{Media Council of PNG}

We are also blessed with a stable, vibrant and forward-looking PNG Media Council that is committed to instilling best practice media conduct in our media organisations and media practitioners, and adhering to the universal best practice ethics of the journalism profession. A subcommittee of the Media Council of PNG, the Media Standards Committee acts as a form of media ombudsman. Its task is to ensure fair and factual reporting by PNG media and that media organisations and media practitioners adhere to highest ethical standards. The PNG Media Council is a recipient of generous funding support from AusAID to assist its media capacity building training programmes in Papua New Guinea.

In speaking to the topic, let me say that journalists in PNG, the wider Pacific - and the world over, for that matter - are free to write news stories and commentaries as long as what is written for newspapers, radio and television is in keeping with the recognised ethical standards of journalism. Where there is freedom, there are also bound to be attempts to usurp that freedom. Often those wielding economic and political power concoct schemes to harass, intimidate and threaten media organisations and media workers for allegedly meddling with their so-called 'holier than thou' corporate, political and public image.

The PNG experience is that once or twice in the last 35 years, resident 
foreign correspondents have been threatened with deportation by the government for so-called 'negative journalism' on PNG affairs. A well-known Australian journalist and Pacific correspondent of the Australian Broadcasting Corporation (who is married to a PNG woman) was actually deported - but not because he had misreported offensively on PNG affairs. His crime was that $\mathrm{ABC}$ Television went to air with an alleged military coup story which - in the assessment of the movers and shakers in the PNG government-reflected negatively on the reputation of PNG political leaders of the time.

From time to time, lawsuits are threatened or taken out against media organisations, journalists and editors; but in most cases these fizzle out and become non-issues. In terms of weaknesses confronting PNG media and media workers, the absence of quality training for journalists, poor pay and conditions of work drive away promising and upcoming journalists from mainstream media into public relations and other spin jobs in the government and private sector where pay, conditions of employment and superannuation are more attractive and secure. A further weakness is the absence of a professional organisation such as a society of journalists which could act as a vehicle to promote the professional concerns of journalists in a media ownership environment that is dominated by foreigners.

\section{Media education}

Our opportunity to thrive as a free, vibrant and robust media industry in PNG hangs on our two university-level journalism schools producing quality future journalists. The Divine Word University (DWU) has surpassed the University of Papua New Guinea (UPNG) journalism school to become the larger school. UPNG has suffered and deteriorated to a stage where it needs immediate financial and teaching resources such as teaching materials and quality lecturers and tutors. DWU is a recipient of generous UNESCO financial assistance and has improved with such assistance. The same assistance would help the UPNG school and I appeal to UNESCO to give such assistance.

I am not here to rattle off statistics and data on media freedom and the lack of such freedom, nor am I telling harrowing experiences of populations in conflict situations who do not experience freedom of information, are denied their right to access knowledge, have no freedom to express their views and do not have the luxury of a free and democratic media. We in the Pacific are very lucky and privileged people. We live in a peaceful part of the world and 
we must always be grateful for what we have despite the limitations and challenges of not having access to all the modern life-support conditions enjoyed by more affluent and economically well-developed nations. Our ancestors have lived in Pasifika since time immemorial and we, and generations after us, shall do likewise if rising sea levels and climate change do not render us extinct.

\section{Ethnically diverse society}

Let me say without any malice that my own nation, Papua New Guinea, is not perfect by any standard but we are proud of who we are, how many we are and what we have in terms of our natural wealth, cultural, political and social diversity. We are an ethnically diverse society as well with more than 1000 tribal groupings who speak more than 800 language dialects.

Papua New Guinea is an integral member of the Pacific community of small island states. We are lumped in with sub-regions known as Melanesia, Polynesia and Micronesia in the vast Pacific Ocean. Some of these island nations-including Papua New Guinea-have been independent for less than 50 years. This year, Papua New Guinea is in its 35th year as an independent nation.

As emerging and evolving nations, we have leap-frogged into the modern Internet age without having faced the trials and tribulations of the various cultural and industrial revolutions experienced by today's mature democracies in the so-called developed world.

The perception that we are 'cut-and-paste or copy-cat democracies' could not be further from the truth. Such dismissive perceptions should not negatively influence the assistance and resources that the peoples of the Pacific need to build their educational, political, social and cultural depth and capacity and to preserve the richness of their ancient cultural, political and social norms.

In our own way, today's Pacific people are proud standard bearers of colourful ancient cultures and civilisations that practised a variety of social democracy based on what modern anthropologists, political and social scientists like to call rule by consensus. We in the Pacific had, and still have, in some island states powerful chiefly structures and systems that oversaw communal and social peace, harmony, good order and basic survival.

Freedom of information and the right to know have been priceless values that have underpinned the existence of the community of Pacific island states since time immemorial. UNESCO would do Pacific peoples proud by involving our media people more prominently in its media training and 
awareness programmes and supporting Pacific media generously in our quest to develop skills, capacity and media institutional knowledge.

Susuve Laumaea is interim co-chair of the Pacific Freedom Forum, an award-winning Papua New Guinean public affairs journalist and a columnist on the Sunday Chronicle. He lives in Port Moresby.This address was made at the UNESCO World Press Freedom Day Conference at the University of Queensland, Brisbane, 1-3 May 2010 as part of a 'Media freedom in the Pacific'panel.

suslaumaea@gmail.com

\section{PACIFIC MEDIA CENTRE}

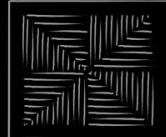

PAEIFIE

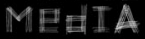
EENTRE TE AMOKURA

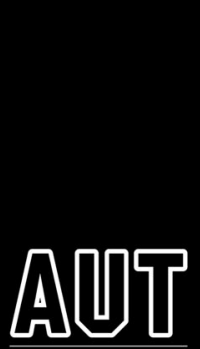

UN IVER S I T
The Pacific Media Centre (Te Amokura) is the only media research and community resource centre of its kind in Aotearoa/New Zealand and has a strategic focus on Māori, Pasifika and diversity media and community development: It was established by AUT University's Faculty of Design and Creative Technologies in 2007, having evolved from a cluster of research and community collaborations within the School of Communication Studies.

PMC activities include:

- International book and research publication

- Publication of the peer-reviewed Pacific Journalism Reviewresearch journal

- Publication of Pacific Media Centre Online as a media resource and postgraduate outlet

- Publication of Pacific Media Watch, a regional media monitoring service

- Journalism and media research opportunities

- Asia-Pacific internships for postgraduate students

www.pmc.aut.ac.nz | pmc国aut.ac.nz 
Copyright of Pacific Journalism Review is the property of Auckland University of Technology and its content may not be copied or emailed to multiple sites or posted to a listserv without the copyright holder's express written permission. However, users may print, download, or email articles for individual use.

http://www.aut.ac.nz/depts/commstud/journ/pjrsubs.shtml 